\title{
Relationship between Natural Economic Resource and Vocational Choice among Nigeria Youth: Psychological Implications
}

\author{
Mary Basil Nwoke ${ }^{1}$ \\ ${ }^{1}$ Department of Psychology, University of Nigeria Nsukka, Enugu State, Nigeria \\ Correspondence: Mary Basil Nwoke, Department of Psychology, University of Nigeria Nsukka, 41000, Enugu \\ State, Nigeria. E-mail: marybasil.nwoke@unn.edu.ng
}

Received: May 18, 2014 Accepted: June 25, 2015 Online Published: December 21, 2015

doi:10.5539/ass.v12n1p84 URL: http://dx.doi.org/10.5539/ass.v12n1p84

\begin{abstract}
This study investigated the relationship between natural economic resources and vocational choice among Nigerian youth. The study grouped the country into three regions, eastern, western and northern regions. This study, first of its kind, explored vocational choice among Nigerian youth. Thirty-six participants, twelve from each region (6 men, 6 women) completed the semi-structured interviews and qualitative data collected was analyzed using a grounded theory approach. The findings presented a preliminary understanding of the relationship between natural economic resources and vocational choice among Nigerians. Qualitative interviews unveiled the presence of natural economic resources that provide vocations to Nigerians. Palms in the east provide the greatest vocational choice. Cocoa in the west provides the greatest vocational choice. Game reserve in the north gainfully employs people. Psychologically, people value the gift of nature in their locality. Finally through thematic analysis, the study revealed that things have changed with education, science and technology. Some Nigerians have become entrepreneurs by utilizing the natural resources prevalent in their environment. Entrepreneurs play an integral role in creating job opportunities and alleviate unemployment in Nigeria.
\end{abstract}

Keywords: employment, skill- acquisition, economic resources, vocational choice, youth

\section{Introduction}

Natural economic resources in Nigeria have motivated vocational choice among Nigerians especially youngsters. Geographically Nigeria is zoned into four regions these are east, west, north and south. For the sake of convenience this study grouped Nigeria into three regions as; east, west and north. In the east there are palm trees and mineral oils, in the west there is good soil for cocoa, cotton, rubber plantations and rich forest for the growth of plywood, and the north is endowed with tin ore, good grassland for cattle rearing which produces a lot of hides and skins; used for leather work of all types, other species of cows which produce natural milk; also good soil for the production of groundnuts, assorted types of vegetables, assorted types of grains and cereals. These natural economic resources are values which offer lucrative job opportunities and are inculcated to Nigerians as early as five years. Human beings in these regions are identified with the diversities of values attached to natural economic resource prevalent in their localities. These regions have dominant gifts of nature, which provide means of livelihood for the indigenes. Udo (1978), Abony (2007) and Okonkwo (2012) observed that the climate and vegetation of a region determines the type of natural economic resources prevalent in each region of Nigeria. Natural economic resources considered include: land, water, climate and bushes because they are wealthy sources that enhance the gifts of nature. In Eastern and Western regions, there is heavy rainfall and natural humidity, while in the north there is scanty rainfall and dry weather. The dry weather gives accommodation to assorted games. Most families in Nigeria adopt vocations related to natural economic resources prevalent in their localities.

\subsection{Eastern Region}

In eastern region there are palm trees which have 'multidimensional strata' or multi phases and provide raw materials for assorted uses. For example palm oil is used for making soap and pomade of all kinds. Palm kernel oil is extracted and used for making various kinds of useful items like cough syrup. Kernel oil serves as natural medication for treating children's convulsion and other sicknesses. From palm tree, raw materials are execrated for making baskets, broom sticks, local beds, chairs and kitchen utensils. Palm produces sweet wines which cheer people's mind and make them happy. Palm trunk is used for building bridges and local warehouses. Palm 
trunk is sawed into planks for building houses and the fronds are used for roofing. The tonny part of the palm frond is used for making fences around the house. The palm is an extraordinary economic resource because as its parts are many so also are the youth and other people who chose the different dimensions as their life vocation.

Where fine clay soil is found in the east, the inhabitants use the soil for making pots of assorted kinds and sizes for kitchen utensils, flower pots and verses; and pots for storing water and preserving grains. Fertile and arable portions of land are used for agricultural purposes and assorted cash and economic crops are cultivated. People from eastern region profitably make use of the gift of nature in the form of land for agricultural purposes, water for fishing and bush for hunting. Easterners produce assorted food items and are engaged in the farm work almost all the year round, for they are either planting or harvesting. Some part of the east has mineral salt deposits and the inhabitants engage in salt cake baking. Those who live along the river-rine areas engage in fishing as their occupation. In the south-east which is the home of the oil producing communities, before the discovery of oil in commercial quantity, the communities were fishers and hunters. They produced the greatest quantity of fish and bush meat and supplied them across regions. In some part of the south -east, where good and viable trees grow, such trees are used for building/carving canoes which provide means of water transport till date and some people hold on to it as their vocations and means of livelihood.

Thick forest provides a lot of medicinal plants, together with other raw materials for medication. Raw materials for medication created golden opportunities for the inhabitants to engage in traditional medicine, while many others are engaged in collecting the raw material for medication as their occupation and sell them across regions and across-cultures. The indigenes share in those gifts of nature and are initiated into the use of medicinal items and plants as early as five years.

\subsection{Western Region}

In western region, the land is extremely fertile for the production of cocoa, cotton, banana, plantain, tobacco and rubber plantations. Here families have their own acres of land for all kinds of cash crops and economic trees grown. Different economic plantations is instrumental for the establishment of such industries like textile, cotton mills, Cadbury, Cocoa kola industries, bakery industries, yam flour and many others. In western region many renowned personalities are engaged in mechanized farming, which produces raw materials to feed the indigenous industries in Nigeria or engaged in supplying raw materials to other parts of Africa and beyond. In some part of western region people who are gifted in art works use the woods for sculptural work and building materials. People are engaged in wood cutting and saw business. The traditional western region people never lacked in naturally endowed job opportunities and most people in the western region are self-made entrepreneurs (Onaiyekan, 2006; Nwoke, 2011b; Okonkwo, 2012).

\subsection{Northern Region}

Northern part of the country is richly endowed with good grassland for rearing cattle which produce hides and skins for assorted types of leather works, such as shoes, bags, sacks, belts, hats and so on. The north has arable land for the production of groundnuts; hence the north is identified with pyramid bags of ground nut produced yearly. The north also produces other economic crops and cash crops such as yam, fruits, assorted grains and cereals for sale. Groundnuts are processed into groundnut-oil and other useful items. The people are busy all the year round processing leather work, extracting groundnut oil from the seeds for multi purposes, planting or harvesting. The presence of tin ore motivated many people to engage in blacksmith work and the production of all types of metal and iron works. Nigerians initiate the youngsters into family's vocations as early as five years.

\section{Review of Related Literature}

Aaron (2003) and Enyinla (2006) observed that regions cherish the items found in their regions, and the natural economic resources provide the people with job opportunities. Values of these natural economic resources are inculcated to the members of each region early in life. Implicitly value relating to the young children accompanying their parents and guardians to the farm or other business enterprise early in life at about five years is a lucrative method of learning to farm or learning the business thereby putting the children to the line of vocational choice. Also early apprenticeship to some hand crafts persons or blacksmith miners are also to skillfully train the individual child on how to produce some items from the raw materials prevalent in his/her locality. This equally puts the child in the line of vocational choice. Nwoke (2011a) observed that most children in rural areas in Nigeria whose parents are skilled in certain professions like hand craft, leather works, textile work, oil extraction mills, salt cake baking, canoe building and so many other things, as adults know how to embark on such projects, as source of their livelihood and occupation.

Adodo, (2007), observed that to sustain the continuity of their professions, most traditional healers inculcate the 
source of traditional medicine to their children early in life. Adodo succinctly attested that those children who carry the bags of traditional healers can describe every beat of medicinal plant or item and can judiciously prescribe treatment for the sick. In a group oral discussion an orthopedic medical doctor disclosed how he entered the profession. "His grand father was traditional orthopedic healer; who used animal bones and pieces of wood (sticks) to treat patients with orthopedic cases; and he used to accompany his grandfather to the forest and thick woods where he gathered herbs, roots, barks and other medicinal items. This orthopedic medical doctor attested that before he started schooling he had known how to set broken or dislocated bones. He finally decided to enter the university to perfect on the vocation".

Havighurst, (1973; Levine, 1986; Masten \& Coatworth, 1998; Santrock, 2006; Nwoke, 2009) observed that the physical surroundings and social interactions provide incentives, opportunities and pathways for growth and vocational choices. The childhood work experiences lay the foundation basis for vocational choices for most people. Nwoke,(1997) observed that the family works like farming, pot making, basket making, canoe carving, salt cake baking, hunting, fishing and cattle rearing, create job opportunities for many Nigerians. Nwoke, (2011b) observed that the use of natural economic resources prevalent in all the regions in Nigeria is inculcated to the indigenes early in life, even though the individual as a child could not do the work meant for adults, the child is put in the line of thought and behaviour expected of the people in such occupation. It could be adduced that the child is conditioned to mental or cognitive learning of such profession. Before the individual child reaches teenage, he/she is already used to the way of thinking, reasoning, interpreting and evaluating the ways his/her people make use of the raw materials prevalent in the environment as a source of work or occupation through which the group earn their living. Nwoke (2011b) further observed that, the type of training given to the traditional Nigerian child makes him/her acquire progressive competence in a wide range of functions and skills which enables him/her to adapt and survive in many different situations.

Nigerian is endowed with diversified natural economic resources and it is hoped that the child is the future custodian of the natural resource values hence the child is introduced to it early.

As the children have been introduced or initiated into the skills from their various cultural backgrounds through informal training, when they enter formal education the skills become more refined. Divergent thinking and creativity are propelled and sustained in children, through effective use of the gift of nature in the environment; and these activities are evaluated in the school. During handiwork or hand craft exercise, a period in the school curriculum every teacher engages his/her pupils in divergent thinking and creativity, by using the raw materials prevalent in the locality to produce something new and different as enumerated in this work. It was observed that, it was through divergent thinking and creativity that science and technology were born and the eventual establishment of indigenous industries or factories, where the raw materials found in the environments are changed into finished products, like ceramic industries and electronic gadgets. In Nigeria, children who came from different regions and who were properly guided at the informal and formal education became masters in the production of some items by using the raw materials prevalent in their environments. For example, those from the northern region, where there are much hides and skins, and who were well guided at childhood, as adults have established leather work indigenous industries, where all kinds of leather work products are produced and distributed across. In western region, cotton and cocoa are instrumental to the establishment of infant industries like Cadbury, cotton mills and textile industries. In eastern part of Nigeria, the presence of good clay and palms, have brought the establishment of small scale pot industries, oil mill industries, broom, baskets and local bed factories. It is observed that many youth from poor family backgrounds, who finished their primary school education, and had nobody to help them to further their studies could resort to the production of such things they are skilled in producing as a means of their livelihood, and sponsor themselves to their further education. Those who are not keen to furthering their education or who did not embraced formal education, but are well trained at their homes on how to be skillful in the production of some of the goods mentioned in this work as children, as adults become self-reliant and sufficient by engaging in the production of such items as their vocation.

\subsection{Objective of the Current Study}

The primary purpose of this exploratory study which may be the first of its kind is to examine the relationship between natural economic resources and vocational choice among Nigerian youth. To examine if educational development, science and technology have affected the choice of vocations among Nigerians youth.

\section{Method}

\subsection{Participants}

The data collection was part of a long term observation by the author on how most Nigerians engage in vocations related to the natural economic resources prevalent in Nigerian localities. For example, those from the east 
engage in palm produce, salt caking, and pottery where fine clay is found and canoe building businesses; those from the west engage in cocoa produce, ceramics and cotton mill (textile); and those from the north engage in leather works and black smith businesses. It is from these that the current study focuses exclusively on the relationship between natural economic resources and vocational choice among Nigerians youth. Specifically, 36 participants (18 men and 18 women) (14-19) years with a mean age of 16.5 years, (20-25) years with a mean age of 22.5 years were involved in the study. The choice is because (14-19) years engage in natural economic resource small scale businesses; while (20 -25) years are the group who have established their own small scale industries or factories making use of the natural resource materials prevalent in their localities, and have become entrepreneurs in their vocations or occupations. So for a proper representation and to obtain the true description of each region's natural economic resources of the population involved in this study 36 healthy youth freely participated in the study. For the sake of confidentiality participants were identified with numbers and the first letter indicating their region, for example (E1-E12 showing those from the East, W1-W12; those from the West; N1- N12 those from the North).

The researcher got to the various regions with the help of two research assistants and a snowballing method was used to recruit the 12 participants from each region at different times. The snowball sampling technique involves the use of initial contacts to identify other potential participants (Clark-Carter, 1999). All the participants were born and raised in their homes in their respective regions in Nigeria and their parents are Nigerians by birth and were raised in their regions. All the participants had formal education to some extent and came from different family backgrounds in terms of socio-economic status. For instance, 6 of them had university degrees and came from relatively high class families. Eleven of them had Ordinary National Diploma (OND), 10 participants had Higher National Diploma (HND) and these came from high/middle class families. 3 of the participants had senior secondary certificate education (SSCE); 3 other participants had junior secondary certificate education (JSCE); 3 went Sunday school and the (SSCE, JSCE \& Sunday school) groups came from low class families. All the participants speak English language, Pidgin-English and local languages. For better understanding and better coding of information obtained, two graduate research assistants were employed from each region.

\subsection{Data Collection and Analysis}

Due to the fact that much attention has not been given to the relationship between natural economic resource and vocational choice among Nigerian youth, thematic analysis and broad use of grounded theory were chosen to develop an initial understanding of the core issues in this sample. Grounded theory allows theories to emerge from raw data in an inductive manner, while using few or no preconceived hypotheses to hinder the emergence of such theoretical prepositions (Cresswell, 1998; Glaser \& Strauss, 1976). The researcher and the two research assistants conducted interviews in a semi-structured manner and explored issues such as the importance of some gifts of nature like palm trees, sea -bamboo palms, fine clay deposits; mineral salt deposits found in the eastern region, and how these natural resources pave the way of vocational choice for the people. In the west, the researcher with the assistants explored how such items like cocoa trees, cotton plants, thick rubber forest, thick woods of exotic trees, bushes of bananas and plantains found all over the place, can be sources of vocational choice for the indigenes. In the same vein the researcher and the assistants investigated how hides and skins from herds of animals found in the northern region, pyramid bags of grains grew in the north and mineral deposits like tin ore serve as sources of vocational choice among the people (See the appendix).

The interviews which typically ranged from 45 to 90 minutes in length were recorded and carefully transcribed. Data from the transcribed interviews were independently coded by the two research assistants including the principal researcher. The organizational method led to the formulation of a theoretical model that encompassed universal themes and concepts that emerged from 12 qualitative interviews according to regions. The process of identifying themes started immediately after the first interview was completed following Glaser and Strauss's (1967) model of constant comparative methodology was modified as each subsequent interview was completed. Qualitative interview continued to be conducted until a saturation point was reached and no more new themes emerged from the interviews. To limit biases and to ensure that all possible themes were identified, explored and incorporated into the theoretical model, coding was conducted independently by the researcher and the two research assistants. They held a long discussion and some modifications were made.

\section{Results}

Results are organized around the information obtained from each region from (1- 12) respondents.

\subsection{Eastern Region}

Tell me a little about yourself. Can I know a little about your region? 
Do you identify with values of natural economic resources in the life of your people?

Respondent E1 said: Yes I identify with my region. Eastern region is endowed with invaluable natural economic resources, which offer vocational opportunities for many Nigerians.

Eastern region is endowed with a wealth of rich natural economic resources, which of these is the most important and what distinguishes it from others?

All the twelve respondents (E1-12) unanimously attested that Eastern region is endowed with a wealth of natural economic resources and prominent among these is the palm tree. What distinguishes it from other natural economic resources is that it has many phases and each phase gainfully engages people differently as their life occupation.

Respondent E1 said: in Eastern region while the palm is at the nursery, it is some people's vocation to gather the nuts (seeds) and put them in nursery beds section. Another group is engaged in transplanting the tender palm plants. Some other people will tend the young palms to maturity. When the palm starts producing, it is some men's job to climb the palm trees and cut down the ripped palm heads. It is some people's job to peel and sieve the chaff and pack it ready for oil mill. At oil mill it is another people's occupation to heat the ripped palm nuts ready to extract the red palm oil, kernel and fiber. It is another people's occupation to work at the oil mill for extraction of red palm oil and other produce. It is yet another people's vocation to further process the red palm oil for assorted uses. The cracking (breaking) of the dried palm nuts to extract the kernel seed is another phase of vocation.

Respondent E.2 said: in my locality most people's occupation is to extract the kernel oil, from the kernel seed. Another group of people further process kernel oil in soap/ pomade industries. To produce traditional cough syrup and ointment for treating scabies and endemic ulcers from kernel oil is a job choice.

Respondent E.3 said: my grandmother is a traditional midwife and she uses palm produce for so many domestic chores. She uses the palm kernel oil to produce some medicine used in treating gynecological cases and diseases; treating convulsion in children and other infants' sickness. She told me that she uses the extracts from the palm to produce some medicine which she gives to a woman in a tough child bearing labour.

Respondent E. 4 said: in my locality when the palm head is cut, some palm fronds usually fell with the head. People carry the fronds and transform them into different useful items or finished products like broom sticks, baskets of different sizes and designs, long local trays and others things as their vocations. Small scale business centers for the sale of palm produce accessories abound "my father told me that his father (my grandfather) was a local basket maker and people from across regions came to buy from him".

Respondent E.5 said: Palm trees produce sweet alcoholic drinks (palm wine). "There are many men from the east who are professional palm wine tappers and my father is one" "my father made his life in this occupation". "He is both professional palm wine tapper and seller". There is an exclusive local market where palm wine is sold.

Respondent E6.said: "my people use the palm trunk for so many things". For example my uncle is a builder and he told me that when the palm tree is no longer producing nuts, it is felled and the trunk is sawed into planks for building bridges, houses and fences.

Respondent E.7 reported the presence of bamboo palm. Bamboo palm grows in the water banks, especially where they are densely clustered. "in my place many people engage in sewing the bamboo leaves used as local umbrellas. Others prepare the leaves for roofing houses. There are people who engage in using the bamboo fronds and the sticks to make assorted local items such as mats, beds, chairs, window blinds, wall-brooms, seats, and ceiling their houses. The bamboo palm produces sweet wine and some people are professional bamboo palm wine tappers".

"My maternal grandfather ferments the bamboo palm wine into another local alcoholic drink called 'kaikai' as his occupation". There is a local market where palm bamboo produce are marketed. More recently because of its usefulness, some people have chosen as their vocation to gather the bamboo seeds, make nursery for them and later transplant them.

Respondent E.8 reported: that mineral salt (sodium chloride) deposits are also found in eastern region and people in such locality engage in salt cake baking vocation and there is local market for selling the caked salt. "my parents engage in salt cake baking business.

In eastern region there is good deposit of fine clay. What is the fine clay used for?

Respondent E 9 attested that the fine clay is precisely used for pot making. Majority of the people who are professional pot makers are women. "my paternal grandmother was a professional pot maker. She made different 
sizes and artistically decorated them. The pots are used as kitchen utensils, such as cooking, flower vases, water or grain storage. There is a local market where pot makers assemble their products for sale. Respondent E9 attested that most people are initiated into pot making from the age of five, by the time they reached the age of fifteen or twenty years they have become professional pot makers".

Respondent E10: reported that the presence of the Imo River offered a golden opportunity for many people to engage in fishing as means of living. "Many people from my home engage in fishing occupation. Fish caught are sold in the local market and some people engage in carrying the fish across regions and boarders for sale".

Respondent E11: "indicated that at the bank of the river grows popular trees used in carving or building canoe. Canoe provides invaluable water transport service to date. Some of my friends who live in river bank localities are professional canoe builders and as some of the old adults retire from active canoe building the young ones the youth take over.

Respondent E12: reported that lime stone deposits are in some parts of eastern region. This mineral deposit has led to the establishment of cement and ceramic industries/factories. "I work with cement factory". All the respondents from the Eastern region (E1-12) indicated that the discovery of mineral oil (hydrocarbons) in commercial quantity in some part of the East since 1958 has gainfully employed many youth in different departments.

\subsection{Western Region}

Tell me a little about yourself and a little about your region

Do you identify the value of natural economic resources in the life of your people?

Natural economic resources abound in your region, which of these resources do you consider being the most important; and what distinguishes it from other resources?

All the respondents, (W1-W12), said, to say which is the most important may be difficult, because cocoa is very important, cotton is very important, tobacco is very important, rubber plantation is very important, kola-nut trees is very important, the wood (forest) is very important; including the quality of western region soil which harbour bushes of bananas, plantains and assorted cash and economic trees.

It is true that all these items are very important. But in the order of priority tell us the most important and state why such is the most important?

All the respondents (W1-12) attested that Cocoa is the most important.

Respondent W1 said: "cocoa grows in every part of western region. It creates job vocations to many people in the western region and has many phases which gainfully engage people at different periods". For instance "in my locality some people professionally take care of cocoa plants at the nursery. There are others workers who are employed for transplanting the cocoa plants. It is another people's occupation to tend the tender plants to maturity. Other workers engage in fumigating the cocoa plants against pests.

Respondent W2 indicated that "when cocoa is ripped there are people who do the harvesting. It is still some people's job to carry it from the cocoa farms to the local factories where the cocoa seeds are sieved from the pods. It is still another people's job to dry the seeds. It is some people's occupation to sew the sacks for packing the cocoa seeds. When it is dried another group of people will baggage it for transportation". "Cocoa produce is used as raw materials in the indigenous industries that produce beverages in the western region which include Cadbury industries, candies, cocoa kola, chocolate and others cocoa products. Cocoa as raw material is transported to other parts of Nigeria and across boarders for the production of other invaluable items".

Respondent W3 said: "Cotton is important economic resource that gainfully engages people. Like cocoa some people engage in nurturing the cotton seeds in the nursery section. Other workers do the transplanting of the plants. It is some others' occupation to weed the cotton plantation until it matures and produces the white cotton (wool). It is some people's job to pick the wool from the farm. At the local factory some people are engaged in extracting the seeds from the wool. It is some people's job to process the cotton for pharmaceutical uses. It is some people's job to get the cotton ready for textile mill. At the textile mill factory it is the professional vocation of some people to transform the wool into all types of wears". "my father works with the textile mill".

Respondent W4 disclosed: "as a vocation some people engage in the extraction of cotton seed oil used for treating some skin diseases and the production of some pharmaceutical products". There are some establishments in my town that specialize in extracting cotton seed oil for many purposes such as preservative and manufacturing local source condiments. Some people from my locality vocationally engaged in the extraction of cotton seed oil. 
Respondents W 5 attested that: "in Western region tobacco plantation gainfully engages people too". "my father has large acres of tobacco plantation and he has many workers in various departments, or sections, such as the nursery section, some others do the transplanting".

Some people are engaged in weeding the delicate plant until it matures. It is people's jobs to pick the matured leave from the plantation. Different people are engaged in drying the leave. When dried, it is the occupation of different people to take it to where it is further processed into different brands of cigarette or snuff.

Respondent W 6, reported that "rubber is another economic resource that engages people like the palm or cocoa". "The seeds are collected and nurtured in the nursery. When the plant is ready for transplanting another department does it. Weeding or brushing rubber plantation is another big phase that engages people; this group fumigates the plantation against any pest. When the rubber tree matures, tapping of the whitish gummy liquid engages many hands because a lot of processes is involved at this stage to safe guard the economic values".

This respondent indicated that "the whitish gummy liquid goes into different processes for the production of assorted items of rubber products; such items like plastic foot-wears, plastic buckets, plastic seats, plastic plates, plastic spoons and other plastic kitchen utensils". "many Nigerian youth are gainfully employed in rubber products departments".

All the respondents unanimously agreed that the forest (wood) found in the western region harbours so many economic resource items which people choose as vocations.

Respondent 7 said: "there are people who are professional tree fellers. There are others whose job is to carry the wood out of the forest to the factory where it is sewn into plywood and planks for building houses and other various uses". "Categories of carpenters use the forest woods in carpentry works". "Wood is also used for carving ivories and sculptures". "My grandfather and many others from my place made their living from wood carving; and now we the young ones have taken it up as vocation".

Respondent W8 observed that inside the forest there are different economic resources which people found as means of their livelihood. Some youth take it as their vocation to go into the forest to pick items like banana of assorted types; snails of different sizes take them to towns and sell them and make their living. This finding supports Oloko (2002) who observed that people can engage in or tap the resources found in their localities to make their living.

Respondent W 9 indicated: "the forest harbours invaluable medicinal items, many Nigerian youth engage in gathering medicinal items and selling them to medicine people across regions and across cultures".

All the twelve respondents (W1-12) unanimously attested that kola-nut tree grows as a wild tree in the bush.

Respondent W10 added "because of its usefulness in Nigerian society, the tree is now tended and planted around the house or a plantation mapped out for it". "The wise saying among Nigerians is that 'the western region cultivate and produce kola- nut, the northern region consume it, and the eastern region made it 'sacred' the saying implies that the westerners produce kola-nut, the northerners buy and eat, to the extent that it is shown in their mouths; the easterners attach much 'sacred' meanings to it in respect to their cultural value system, because of the fact that in any social gathering among the easterners, kola-nut must be presented". As an economic resource, many people from my home choose the production of kola-nut as a live vocation and make their earnings.

Respondent W11 disclosed that: in some localities where mineral deposits like lime stone is found, in recent times, cement or ceramic industries have been established, and such has created assorted job opportunities in my own locality there are iron and steel deposits. Iron and steel industry has been establishment which has gainfully employed many young people in different areas. "My senior brother and I work with iron and steel industry".

Respondent W12 said that: "the whole of western region has very rich soil for agriculture. Every family in the west has mass acres of land for farming. Youth are engaged all the year round, for they are either planting or harvesting. With science and technology many people practice mechanized farming.

\subsection{Northern Region}

Tell me a little about yourself. Can I know a little about your region?

Northern region can be described as grassland area of the country.

Do you identify with the value of economic resources accruing from the grassland in the life of your people? Respondents answered in affirmation.

All the respondents (N1-12) indicated that Northern region has luxuriant grassland. 
Respondent N1 said: "our type of vegetation makes it possible for the production of assorted vegetables, assorted grains, assorted potatoes; other cereals and pyramid bags of ground nuts"

Respondent N2 "observed that because of the type of vegetation my people rear different kinds of animals that produce hides and skins, we use these in producing all types of leather works".

Respondent N3 indicated that some farmers rear special cows for the production of natural milk. "This natural milk is further processed inform of yoghurt which young people carry about as their job".

Respondent N4 said: "our northern vegetation provides habitation for wild animals; such as lions, zebra, elephants, hippopotamus, hence we have game reserved in some parts of our region, like Yankari".

Respondent N 5 said: "in all honesty Yankari game reserve has attracted government attention and Yankari has become tourist centre. At that centre there are many works to be done by young people with differing skills. My siblings work at Yankari game reserve".

Respondent N6 said: "Northern region produces sugar cane in large quantity. Many farmers and entrepreneurs are sugar cane producers. My great grandfather had mass acre of sugar cane plantation. My father and my uncles took over from their father. For years or generations, sugar production has been our family's occupation. "we are known for it "and we the young ones are now controlling it".

There are many businessmen and women who deal in sugar cane. These buy from us and from others in the region and transported it to across regions and countries.

Respondent N7 said that "the presence of the river provides a great opportunity for fishing jobs".

Can you tell me how these items provide vocational choice or job opportunity to most Nigerians?

Respondent N8 said: "the rearing of assorted animals provides hides and skins for commercial leather work. Young people are gainfully employed in the production of items like leather shoes, leather bags, leather boxes, leather cap (hat), leather belt, and assorted leather furniture for house decoration; people make leather work-mats as their means of livelihood. For the species of cows that produce natural milk, some families have it as their vocation to rear such animals, it is some young people's job to extract the milk from the cow, and it is another people's job to purify the extracted milk ready for consumption."

Respondent N9 indicated that "some youth are employed to carry the milk to the places where it is needed in the region or across regions. Most women (youth) from this region carry their containers of fresh milk about the places looking for customers. People have restaurants where they sell fresh milk and yoghurt, while some people hawk it about".

Respondent N10 indicated: "as the vegetation provides the opportunity to grow assorted vegetables such as onions, tomatoes, carrot, lettuce, cabbage; green beans, green pepper, cucumber, water melons and many others, many different young people are engaged in the production of these different items. Different young people are engaged for the carrying of these items to the places where they are marketed".

Respondent N11said: "my region produces pyramid bags of ground nuts, pyramid bags of assorted grains, and cereals. Different people take the production as their live vocation. As different people engage in the commercialization of these items as their live vocation. Because of our vegetation we are either planting or harvesting". The respondents attested that some Alhajis (Entrepreneurs) from the north are given names after what they produce for example, Alhaji 'chinkafi' known for the production of rice.

Respondent N12 observed that: "northern region type of vegetation makes for the growth of the ever producing moringa plant. Moringa plant 'is the world supermarket on a tree'. Since moringa came to be known, people collect the leaves, dry it, grind it; pick the seeds and package and sell it to people. Yet some young people extract the oil from moringa seed, bottle it and sell. The great plant moringa offers vocations to people in three dimensions, collecting the leaves, gathering the seeds and extracting the oil. This particular gift of nature moringa serves as source of vocational choice, food and mineral supplement and medication in Nigeria".

"Mineral deposit tin ore provides the opportunity for black smith work. People who work as black smith produce farm implements like cutlass and hoes, as well as tin containers for fetching or storing water".

\section{Discussions}

Based on the findings of this present study, Nigeria is endowed with a wealth of natural economic resources which gainfully employ many Nigerians youth in their regions.

In the Eastern region palm produce is the most prominent of all the natural economic resources with many phases about 16 of them. The findings of this current study reveal that young people choose one of these phases 
as their live vocation. For example, it is a vocation to care for the palm at the nursery stage, transplant and tend it to maturity. When the palm ripe, it is some men's job to climb and cut the heads. It is a vocation to extract the red palm oil from the nuts ready for use in different departments for the production of assorted finished products, such as types of soap and pomade. The present study reveals that it is a job to extract kernel oil from the hard nuts for the production of different products, including syrups for treating children's sickness like convulsion and skin diseases. The present study shows that palm frond is used to produce assorted accessories for domestic utensils, such as broom sticks, baskets, and chairs. The present study also shows that the palm fronds are used for roofing houses. Also the current study revealed that the palm trunks are used for building houses, local bridges and building fences. And there is a local market where such products are sold. In all these people choose the production, buying or selling of any of these as their live vocation.

The current study reveals that the palm produces some sweet alcoholic drink. The respondents from Eastern region unanimously attested that there are some men who are professional palm wine tappers and these men are handing the vocation batten to their young sons. There are people who are professional palm wine sellers. The respondents attested that palm wine is a rare commodity among the Easterners because palm wine conveys a lot of cultural value mores. In oral communication, all the men respondents from the East indicated that the palm wine unites the living with the ancestral world. There is a particular market where palm wine is sold. People chose it as their vocation as palm wine sellers. Two respondents from the East indicated that there is a particular market day when all the palm wine produced would be assembled to the village square for every indigene of the place to go and drink free of charge.

When asked what did such symbolize? The response is 'palm produce is the most precious free gift of the Creator and it is only men who climb to tap the wine; women do not climb or tap wine, and even at that, not all men can climb; so in the traditional society it was believed that as the living shared the drink and made merry, and greeted each other with blessings, the ancestors also shared and made merry and blessed the living with prosperity'. Then by bringing the palm wine together, any person who wanted to drink had access to it. But things have changed the respondents observed. Nowadays, when the palm wine is assembled, anyone who wanted to drink pays for it. The respondents revealed that in recent times most people do not go to the town or village square to drink together again; rather they prefer to buy the drink from the tappers who take it to their houses at a very costly amount and drink. When asked why such attitude change? The response 'is that people have learnt wickedness, poison people's drink and so become suspicious'.

The current finding presents sweet 'bamboo palm-wine; which if fermented and highly heated turns into strong alcohol called kaikai' People engage in the production and distribution of it.

The bamboo fronds are used in making local chairs, stools, mat, window blind, treys, beds, and local umbrellas and for building thatched houses. There is a local market where bamboo accessories are assembled for sale. The respondents indicated that people engage in the production of the accessories as their vocation. The present finding shows the type of trees which grow at the river bank and used for carving canoe in eastern region. Canoe building is a very lucrative vocation in the East, which. modernity and education have not influenced. The present study shows that mineral deposits like salt offers opportunity for people who engage in salt caking business. The respondents of this study indicated that salt business is vocation among those who know how to handle it. The present study shows that in places where fine clay is located people who live there, especially women are professional pot makers. In places where lime stone is located, cement factories/ ceramic industries are located and such factories and industries gainfully employ many people in different capacities. The respondents affirmed that new innovations have come in the form of mechanized ways of utilizing the natural economic resources. The respondents emphasized that even though there are changes with modernity and higher education, people still adhere to natural economic resources as their life occupation. The respondents attested that most Nigerians find their daily earning through the gift of nature.

The respondents unanimously observed that some people from low family backgrounds and who did not get higher formal education engage in using natural economic resources found in their locality to produce something new and lucrative; while those who have acquired higher education embark on projects that make use of the raw materials found in the locality. The current findings support Onah (2007) who observed that some people who acquired higher education have embarked upon establishing indigenous factories and using the raw materials prevalent in their locality to feed such factories. For instant there is oil-mill industry for extracting palm oil and kernel oil from palm produce in the Eastern region. Furthermore, industries that make use of the oils as raw materials are established where the oils are used for producing so many other accessories.

However, some of the respondents regrettably lamented that things have changed with education, science and 
technology; and many people seem to abandon the traditional source of vocational choice and have gone after white collar jobs. For example the production of the beautifully decorated pots is almost becoming something of the past.

The respondents unanimously attested that most of the local pot makers are dying out and their educated children are not keen in taking up pot making profession, some see it as menial job, hence they rush to urban for white collar jobs. This present finding buttresses Okonkwo (2012) who observed that the declining fortunes of Nigerian ceramics industries have affected the economy; this is because people have abandoned the traditional sources of occupation which boosted the economy in pursuit of white collar jobs. Although the study disclosed that there are few families, who educated their children through pot making and that after graduation, these children established pot making profession in a large scale business in their town, as a way of patronizing and immortalizing their parents' profession.

Based on the responses, so many natural economic resources abound in the West, which gainfully employ young people. The respondents unanimously attested that natural economic resources brought material wealth to the western region people. For example almost all the natural economic resources, employ people of different skills from nursery to maturity. The respondents disclosed that with education most of the crude ways of tending and producing or using these economic resources have changed. For example many Cadbury beverage factories in Nigeria make use of cocoa produce as raw materials and employs people of different skills. The textile mills make use of cotton produce as the raw materials and engage people in different capacities in producing assorted cloths. Cigarette industries use tobacco as their raw material and gainfully employ people of different calibers. There are some factories that produce tobacco in powdered form called snuff equally employ great number of people. Respondents disclosed that some special trees found in the thick forest are used for carving ivories of different sizes and patterns used for decorating houses and cultural activities. While some trees which are medicinal in nature are used for producing curative chewing sticks for the teeth. The respondents indicated that people who produce these items have made their lives in it. The current study disclosed unclassified items in the forest which people gather for natural medication, and sell to traditional medicine people across regions and cultures.

The respondents unanimously attested that things have changed with education, science and technology. For example, some of the sectors where crude implements were used now operate on mechanized system and new innovations are introduced; with this some people who do manual labour are displaced. For instant with education, science and technology there is new patterns of carpentry and executive forms of building household furniture. Conversely people turn round to learn the new patterns of carpentry (upholstery). The respondents indicated that with science and technology factories have been established where the assorted bananas and plantain items are used to produce different types of fruit maid; and these factories gainfully employ people in different capacities. The current findings support Abonyi (2007) who observed that human -centered development activities as an effective strategy towards achieving sustainable development have greatly enhanced socio-economic status of many people, families and countries in Africa.

The respondents from the north attested that due to the climate of the region, assorted grains and vegetables are produced; and these gainfully employ the people at different periods planting or harvesting. One of the major occupations is cattle rearing and the children are introduced into cattle rearing vocation at the age of five years. The present study reveals that from the animals a lot of hides and skins are extracted and used for assorted leader works and some of the animals produce natural milk; and people have used and still using this as their live vocation. The current study reveals that the Yankari Game Reserve for tourism gainfully employs the indigenes. Respondents indicated the deposits of solid minerals tin ore and zinc in northern region, people of such places engaged in black smith as their occupation. Unanimously, the respondents attested that with education, science and technology, things have changed, for example, granary storage where the grains are preserved and stored has been built. The respondents disclosed that with education, science and technology mechanized system of farming and irrigation is built to draw water from Kanji dame to keep both cash and economic crops ever producing.

One of the respondents from the north indicated that his grandfather was a black smith man, who used traditional methods to produce farm implements like hoes, cutlasses and other weapons. This respondent revealed that his own father took after the vocation of his grandfather and used the same methods. But when this youth went to University he read Geology/Mining, after graduation he took up the family vocation and made a drastic transformation in the methods used in producing items associated with blacksmith/mining. This youth /respondent indicated that he liaised with some graduates (youth) from his locality who graduated from different areas of study and they established a factory where most of the raw materials prevalent in their locality are used to produce modern implements. The respondent indicated that their factory has employed many young people, in 
various capacities. The attitude disposition of this respondent is clear evidence that the crust of educational attainment is to be able to diversify ideas, create job opportunities and alleviate people's unemployment issues. The attitude/activity reaction of this respondent is in line with Okolie (2015), who posited that people should make use of what is in their environment to salvage the deplorable condition of unemployment and alleviate poverty, This finding supports Audretsch, Carree andThurik (2002) who observed that entrepreneurship involves particular psychological dispositions. This simply implies that some conscious efforts are required to create the appropriate motivational attitude (intrinsic and extrinsic), which could result in developing entrepreneurship thinking among Nigerian youth as observed in other developing countries. The current findings buttresses Onaiyekan (2006) who reported that countries like Singapore, Hong Kong, Japan, Dubai and other developing countries utilized the natural economic resources prevalent in their environments /countries and developed their countries and created job opportunities for people. This present finding buttresses Igbo and Anugwom (2011), who observed that education, science and technology have brought a lot of social changes and innovations in the contemporary time.

\subsection{Psychological Implication}

Psychologically, people have come to realize the importance of the gift of nature in their environments and their uses in their lives. Psychologically, the entrepreneur is regarded as an integral player in any business culture and also as an engine for job creation and economic growth. Again knowing how lucrative natural economic resource is to humanity, young people become motivated to carter for their environments and maintain gifts of nature since all can be sources of vocational choice to them. For example knowing that the thick forest harbours invaluable items for medication which enhances quality of life, it will be protected instead of setting it ablaze. The youth would know how to make use of what is in their environment as a means of their living instead of going up and down begging or stealing.

\section{Conclusion and Suggestion}

This qualitative study, the first of its' kind has shed light on the relationship between natural economic resources prevalent in the locality and the vocational choice among Nigerians youth. The significance of this study to stakeholders is that it was evident that an understanding of the gifts of nature with which people are endowed gives credence to why people take certain occupations as their life vocations. Although the study revealed that education, science and technology have influenced vocational choice among Nigerians youth, because some of them have rushed to urban areas for white colour jobs; yet some of the educated ones have made tremendous transformation in their localities through the professional skills they have acquired. Hence, Amazue (2011) observed that for Nigerians to join the league of developed nations and consequently reduce high level of unemployment there is needed to develop the culture of entrepreneurial thinking in the populace, and especially by the Nigerian youth. This could be done in a number of ways:

By integrating entrepreneurship into the educational system (from primary to tertiary level), legislating to encourage risk-taking, and national campaigns. An example of the national campaign is the United Kingdom's enterprise week, which was launched in 2004 (Reynold, 2007).

\section{Limitation of the Study}

While the findings of this current study are certainly informative, certain limitations must be taking into consideration. Due to snowballing sampling technique used, the participants came almost from the same locality. When interpreting these findings, it is important to note that some of the respondents came from not-welleducated family backgrounds, which may distinguish the respondents from those from well-educated and high class families. Nigeria is a country with multi-ethnic groups and so vast to be grouped into only three regions, therefore the findings may be indicative of the experiences of this particular locality or ethnic group; however it may not be reflective of other tribes. Without replication studies, it is quite unclear whether the findings of this present study are representative of natural economic resources that provide gainful vocational choice among Nigerian especially the youth. A follow-up longitudinal study should be able to further expand on the findings of this current study.

\section{References}

Aaron, A. A. (2003). Human right violation and petroleum pipeline vandalization in the Niger Delta region of Nigeria. The Nigerian Social Scientist, 6(2), 1-20.

Abonyi, N. N. (2007). Human - centered development as an effective strategy towards achieving sustainable development in Africa. Nigerian Journal of Social Sciences, 4(1), 42-51.

Adodo, A. (2007). New frontiers in Africa medicine. The herbal doctor, diabetes, the secret of it effective 
treatment and management. Journal of African medicine, 2(1), 6-8.

Amazue, L. O. (2011). Psychological predictors of entrepreneurship: Implications for the level of unemployment in Nigeria. Nigerian of Psychological Research, 7, 42-54.

Audretsch, D. B., Carree, M. A., \& Thurik, A. R. (2002). Does entrepreneurship reduce unemployment? Institute for Development Strategies, Indiana University, Tin Bergen, Institute.

Clark-Carter, D. (1999). Doing quantitative psychological research. Hove, East Sussex: Psychology Press.

Enyinla, P. G. (2006). Nigeria. Travesty of oil and gas wealth. Catholic Secretariat of Nigeria, Lagos: Gazue Printers.

Havighurst, R. J. (1973). History of developmental psychology: Socialization and personality development through life span. In P. B. Baltes, \& G. K.W. Schaice (Eds.), Life span development Psychology. New York: Academic Press.

Igbo, E. U. M., \& Anugwom, E. E. (2011). Social change \& Social problems, A Nigerian perspective (2nd ed.). Nsukka: University of Nigeria Press Ltd.

Levine, R. A. (1986). Cultural influences on child development. In W. Douman (Ed.), Child development today \& tomorrow. San Francisco: Jossey-Bass.

Masten, A. S., \& Coatworth, J. O. D. (1998). The development of competence in favourable and unfavourable environments. American Psychologist Special Issue, 53, 205-230. http://dx.doi.org/10.1037/0003-066X.53. 2.205

Nwoke, M. B. (1997). The influence of the home on children's school performance at all levels. Abuja Nigeria: Niger Grafikes Gariki.

Nwoke, M. B. (2009). Factors sustaining human trafficking in the contemporary society: Psychological implication. An International Journal in Africa Ife Psychologia, 17, 161-175. http://dx.doi.org/10.4314/ifep. v17i1.43746

Nwoke, M. B. (2011a). Bio-socio-cognitive adjustment of teenagers in Nigeria. Effects of ethnic groups, age and gender. USA: Lambert Academic Publishing.

Nwoke, M. B. (2011b). Impact of age, gender and social factors on vocational choice among Nigerian adolescents. European Journal of Social Sciences, 19(4), 548-554.

Okolie, A. M. (2015). Global political economy and development of underdevelopment: Different people, same market and glorification of poverty. Inaugural lecture of the University of Nigeria, Nsukka.

Okonkwo, I. E. (2012). Causes of declining fortunes of Nigerian ceramic industries: And its effects on the economy. African Psychologist International Journal of Psychology and Allied Professions, 2(1), 105-114

Oloko, S. B. A. (2002). Child labour and trafficking in Nigeria key issues: Paradigms, methodologies and measures. Paper presented at a meeting on ILO Project on the Integration of child labour courses into the curriculum, organized by the Social Science Academy of Nigeria at Pioneer Hotels, Wuse Abuja, September, $14^{\text {th }}$.

Onah, F. E. (2007). The impact of economic globalization on Nigerian industrial sector. Nigerian Journal of Social Sciences, 4(1), 24-41.

Onaiyekan, J. O. (2006). Making oil and gas wealth serve common goal: Ethical issues. Catholic Bishop Conference of Nigeria. JDPC DRACC. Enugu, November 2-3, 2006.

Reynold, P. D. (2007). Entrepreneurship in the United States. Springer. Retrieved from http://www.entrepreneur.com/tradejournals/articles/171539784.html

Santrock, J. W. (2006). Life span developmental psychology. NewYork: McGrawHill Companies, Inc

Udo, R. K. (1978). Geographical Regions of Nigeria. London: Heinemann educational books Ltd.

\section{Copyrights}

Copyright for this article is retained by the author(s), with first publication rights granted to the journal.

This is an open-access article distributed under the terms and conditions of the Creative Commons Attribution license (http://creativecommons.org/licenses/by/3.0/). 